\title{
Performance of Experimental Bio-Digestion for Pathological and Biodegradable Waste Management at Mwananyamala Regional Referral Hospital Tanzania
}

\author{
Anicetus Honest1 ${ }^{*}$, Josephat Saria ${ }^{2}$ \\ ${ }^{1}$ Ministry of Health, Community Development, Gender, Elderly and Children, Dodoma, Tanzania \\ ${ }^{2}$ Department of Environmental Studies, The Open University of Tanzania, Dar es Salaam, Tanzania \\ Email: *hanicetus@gmail.com
}

How to cite this paper: Honest, A. and Saria, J. (2020) Performance of Experimental Bio-Digestion for Pathological and Biodegradable Waste Management at Mwananyamala Regional Referral Hospital Tanzania. Journal of Environmental Protection, 11, 838-847.

https://doi.org/10.4236/jep.2020.1110052

Received: September 3, 2020

Accepted: October 12, 2020

Published: October 15, 2020

Copyright $\odot 2020$ by author(s) and Scientific Research Publishing Inc. This work is licensed under the Creative Commons Attribution International License (CC BY 4.0).

http://creativecommons.org/licenses/by/4.0/

\begin{abstract}
The aim of the experimental trial was to evaluate the performance of the designed placenta and other pathological waste digester system on the effectiveness of digesting the placenta and its energy recovery (bio-gas) process in Mwananyamala Referral Hospital in Dar es Salaam. A $32 \mathrm{~m}^{3}$ digester is constructed in Mwananyamala Referral Hospital, one inlet of which is to attach to the toilet of maternity ward, where the placentas are flushed directly into the digester, while food waste is fed through another inlet. The slurry of the digester is sent to a sewer/septic tank to avoid further handling. Most fraction of the waste fed into the digester is food waste. In general with the amount of $25.6 \pm 4.5 \mathrm{~kg} /$ day of placenta and $83.1 \pm 14.7 \mathrm{~kg} /$ day of food waste, $2.5 \mathrm{~m}^{3} / \mathrm{d}$ gas was produced. The $\mathrm{pH}$ throughout the study period (that is of 18 weeks) was found to be consistent within the range of 6.3 to 8.0 , while the pressure ranged from $5 \mathrm{kPa}-33 \mathrm{kPa}$. Average temperature within the digester was found to be $30.3^{\circ} \mathrm{C}$. With all the favorable condition, gas production was consistent and hence the system has been successful in management of the pathological waste along with the production of gas as an alternative source of energy for the hospital.
\end{abstract}

\section{Keywords}

Bio-Digester, Biogas, Placenta, Hydraulic Retention Time

\section{Introduction}

Pathological waste disposal presents difficulties for many healthcare institutions. Incineration or pits are often inadequate, expensive and unsafe. Pathological and 
Food waste attracts disease vectors and creates a nuisance as it degrades. Recently, there is an ever-increasing demand for energy, coupled with the shortage of fossil fuels almost all over the world which has created a renewed interest in utilizing renewable energy sources [1] [2]. Searching for alternative renewable energy sources not only is needed for the replacement of fossil fuels, but also meets environmental protection demands [3].

Finding clean and economically feasible energy alternatives for fossil fuels has become a major concern for nations, municipalities and households all over the world [4]. Anaerobic digestion (AD) is an attractive option for healthcare waste treatment practice all over the world in which we can achieve both energy recovery and pollution control [5] [6]. Anaerobic degradation or digestion involves the breakdown of biomass by a concerted action of a wide range of microorganisms in the absence of oxygen. Energy demand and consumption are one of the main reasons for climate change and resource exploitation, at the same time contributing to economic prosperity and quality of life as well as restricting the living standards of humans [7]. One of the alternative energy solutions is biogas technology which converts organic substances to methane as fuel and valuable fertilizer from locally available resources that otherwise would go unused [8]. In the developing countries, biogas is a substitute for firewood and charcoal that can meet the energy needs of the urban, peri-urban and rural areas. Cooking stands for $90 \%$ of the energy consumption in the households of developing countries and access to electricity outside the urbanizations is limited [7].

The general mechanism which ends up in formation of Methane $\left(\mathrm{CH}_{4}\right)$ passes through two steps. The first reaction is fermentative action of acid forming microbes on the substrate $(\mathrm{S})$ to produce alcohol, hydrogen $\left(\mathrm{H}_{2}\right)$, acids and carbon dioxide $\left(\mathrm{CO}_{2}\right)$. The second step is called methanogenesis step where the methane-forming bacteria produce methane $\left(\mathrm{CH}_{4}\right)$ and $\mathrm{CO}_{2}$ (Figure 1).

Most biogases constructed/designed the complex organic matter used that is cow dung digester which is reported having high amylolytic bacteria or they use chicken-dung-fed digester which is rich in proteolytic bacteria.

Healthcare waste treatment and its proper management are global issues with growing challenges especially in case of developing countries such as Tanzania. In Tanzania where proper healthcare waste management has been a neglected issue, increasing the effectiveness of management of healthcare waste is one of the greatest challenges. Pathological waste disposal presents difficulties for many healthcare institutions.

An endless flow of materials through medical facilities end up in large, diverse and toxic waste stream, much of which is carried away to a municipal dumping site or burned in incinerators throwing those hazardous substances into the air and into the surface of earth. Nepali hospitals have successfully demonstrated biodigestion of pathological and food waste and generating biogas for cooking [10]. The plant was initially loaded with cow dung mixed with leftover food waste collected from the hospital wards. After this it was regularly fed with food waste generated from the wards and the kitchen [10]. 


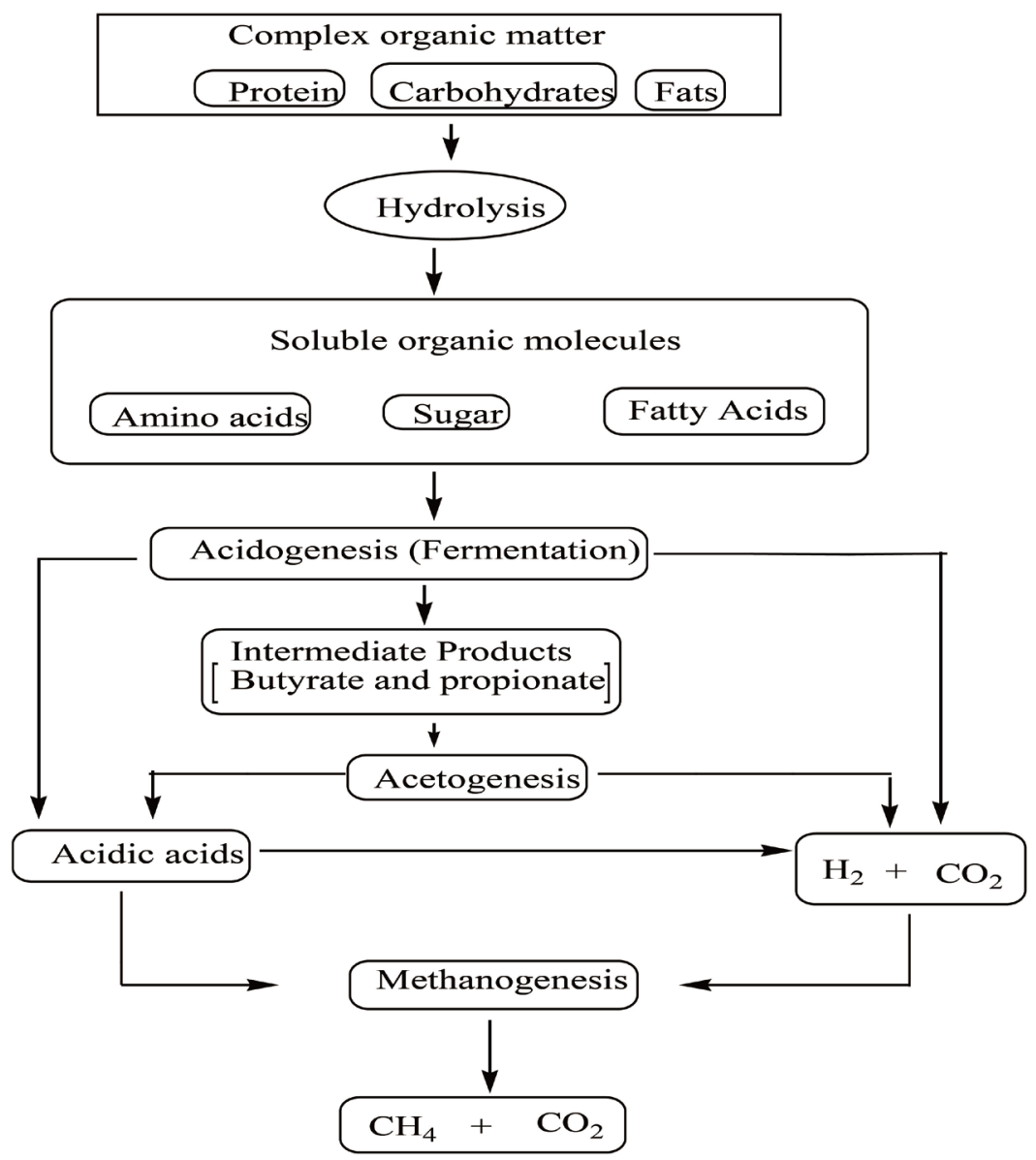

Figure 1. The key process stages of anaerobic digestion [9].

The main objective of this research was to identify and analyze anaerobic digestion process of pathological waste like human placentas as an alternative for the management of healthcare waste especially the pathological waste. The research focused on energy production, relation between temperature and gas production, payback period analysis and green house gases emissions to further analyze the objective. Also the research analyzed the slurry for pathogens.

\section{Materials and Methods}

The biodigesters were built underground with a concrete floor and built up bricks using a water waterproof plaster. A digester of $32 \mathrm{~m}^{3}$ volume was built with a modified toilet in the maternity unit flushes placenta directly into the digester. Food waste was added via another inlet outside. Flow through the system is gravity driven, requiring no power and digester flows into the sewer/septic tank without further handling.

Designs are site specific, based on the amounts of waste, available space and locations of input sources and sewer/septic tank. The placentas were measured in a stainless-steel bucket, and then tilted in the toilet which for this purpose received a larger sewer pipe $(15.3 \mathrm{~cm})$. With one flush the toilet was clean again and the placentas have entered the digester. As the fresh placentas are heavier 
than water, they sink down in the pipe and in the digester and cannot swim up in the pipe. Even later, when they get lighter due to gas production within the placentas, they cannot re-appear in the inlet pipe. The weight of the bucket was deducted from each measured charge. For flushing we add another 10 liter to the hydraulic retention time. The bio-digester was constructed using concrete paver blocks with strength of $35 \mathrm{Mpa}$ and been plastered using cement sand ratio of 1:3 (Figure 2).

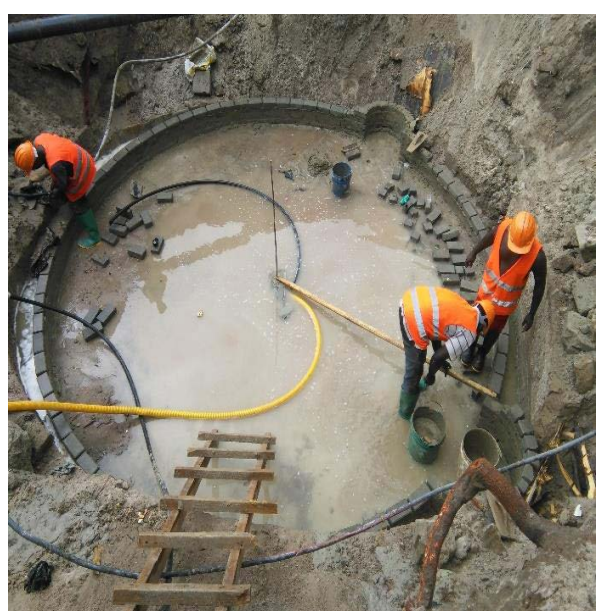

(a)

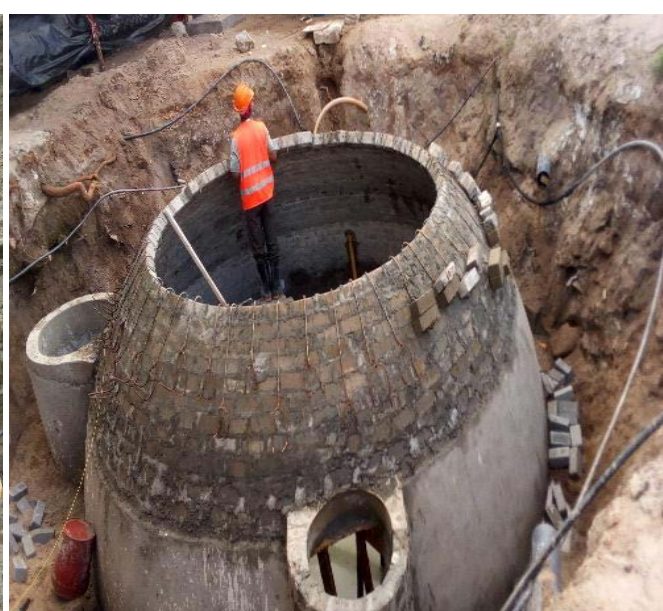

(b)

Figure 2. The design of biodigester.

The radius of the digester is $2.5 \mathrm{~m}$ (Figure 2(a)) and it is spherical in shape with conical bottom. The biodigester was designed with two inlets; one for placenta which is connected to the biodigester with 6 inch pipe and the other for discharging of soft organic materials and it is cylindrical in shape (Figure 2(b)). The outlet is cylindrical in shape and it discharges the slurry from the bio-digester to the displacement channel. The produced biogas that accumulates on the upper part inside the biodigester is collected through IPS pipes to the twin burners located in the maternity ward. In line with the piping system there is water trap for collection of condensation water in the system.

\section{Results and Discussion}

\section{Amount of Waste in $\mathrm{Kg}$ added}

An average $25.6 \pm 4.5 \mathrm{~kg} /$ day of placenta and $83.1 \pm 14.7 \mathrm{~kg} /$ day of food waste was fed to the digester (Figure 3). Food waste is almost three times higher than the placenta for more efficiency of the gas production.

This is higher than the amount of cow dung used elsewhere [11] where 13.5 $\mathrm{kg}$ of cow dung was used. The experiment has been closely monitored and changes in water level, due to the production of gas have been noted. Sudden increase in gas production can be noted due to the activity of the bacteria on organic matter after 9 - 10 days after feeding the biodigester to produce methane gas compared to 18 days detected earlier [11]. 


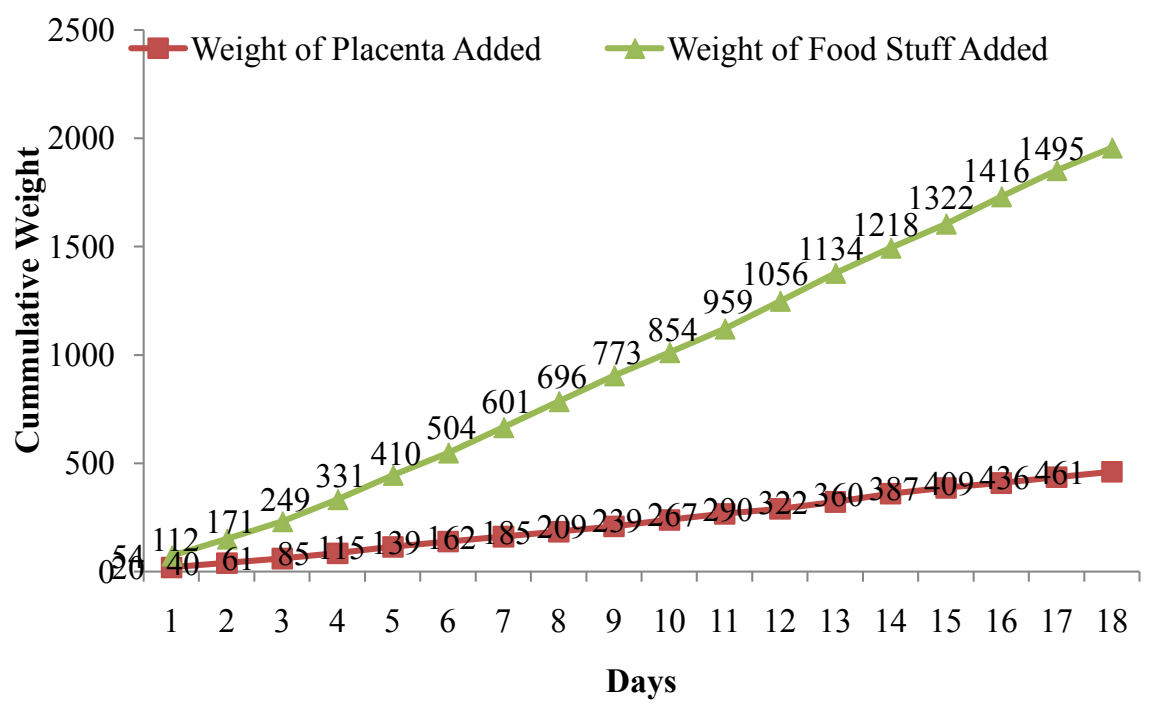

Figure 3. An average placenta and food waste fed into the digester.

\section{Gas Production}

During a total of 18 weeks, $190 \mathrm{~m}^{3}$ biogas were consumed in kitchen for cooking (Figure 4). It must be explained that we can only measure gas consumption, not gas production. The gas production can only be assessed when all gas is consumed, and nothing gets lost. This is here not the case. This consumption measured is on an average $1.5 \mathrm{~m}^{3}$ per day. The regular high pressure measured proofs, that many times in the night, when gas was not used; it was discharged into the atmosphere the displacement channel. This was an average of $1 \mathrm{~m}^{3}$ per day/night.

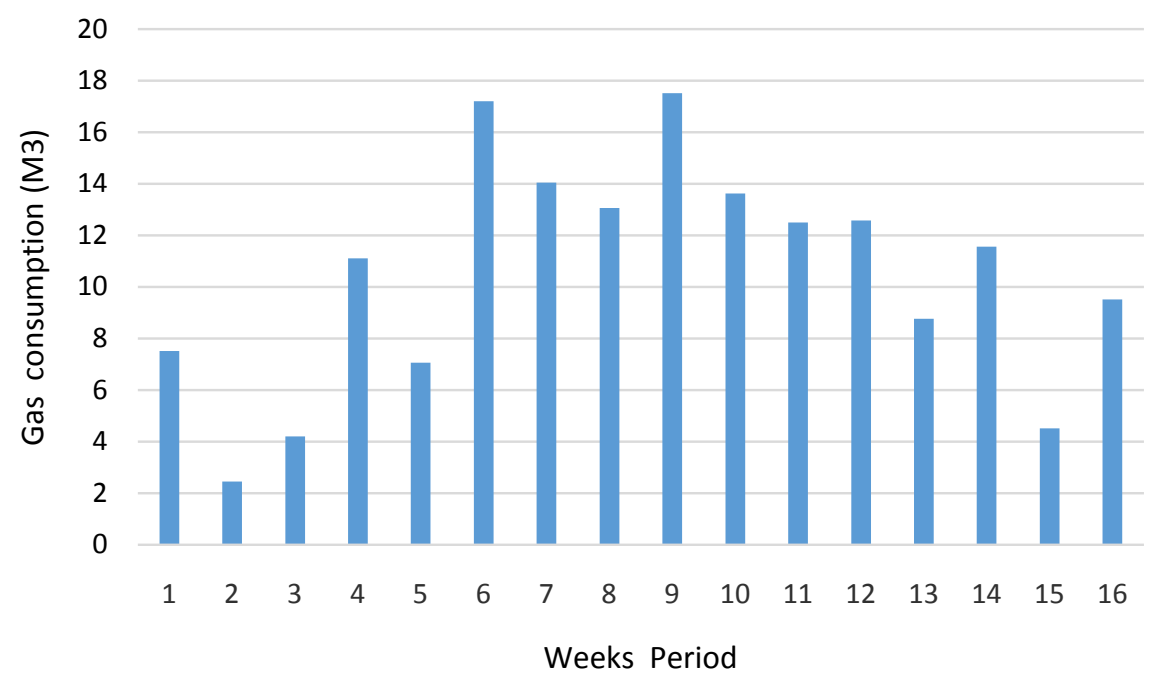

Figure 4. Variation of gas consumption in eighteen weeks.

The gas production is in the range of $17.88 \mathrm{~m}^{3}$ per week (taken the last measured value), summing up to $315.4 \mathrm{~m}^{3}$ total biogas produced during the 18 weeks and a daily gas production of $2.5 \mathrm{~m}^{3}$. This means that at least $126.5 \mathrm{~m}^{3}$ did not go through the gas meter and were released during high pressure (more than 10 
$\mathrm{kPa}$ ) at the outlet of the biogas plant. The reason was at the beginning of this project the hospital had low usage of the gas with fact that it was a new technology to them but also few users than expected to include kitchen for cooking.

To calculate the gas production per placenta we must combine the average solid waste (placentas and food residues) at $79.86 \mathrm{~kg} /$ day with the gas production of $315.4 \mathrm{~m}^{3}$ (total gas): 18 (weeks): 7 (days) $=2.5 \mathrm{~m}^{3}$ biogas produced per day, divided by $79.86 \mathrm{~kg}$ feed material $=32$ liter biogas per $\mathrm{kg}$ feed material. The placentas produce $32 \%$ of the gas while the food residues produce $68 \%$ of the gas. On the average 46 placentas enter per day (one placenta weighs 560 grams). The placentas produce $800 \mathrm{l}$ of gas, the food residues $1700 \mathrm{l}$ of gas. One placenta produces $17.4 \mathrm{l}$ of gas. One $\mathrm{kg}$ of placenta produces 31.3 liter of gas.

The gas production has been measured at $2.5 \mathrm{~m}^{3} / \mathrm{d}$. This value is less than expected and still must be verified. There are several reasons why the value is small. The methane concentration is not known so it is assumed to be the normal average standard of $65 \%$ methane and $35 \% \mathrm{CO}_{2}$. It has been observed in other biogas plants where wastewater flows through that $\mathrm{CO}_{2}$ is absorbed by the water so that the total gas is lessened but the methane concentration is increased [12].

It is also likely that the placentas do not produce very much gas due to the high water content. The value per $\mathrm{kg}$ feed material is $45.45 \mathrm{liter} / \mathrm{kg}$. The food residues alone would produce $60-80 \mathrm{liter} / \mathrm{kg}$. It is also likely that over time the gas production will rise as the sludge in the digester will slowly rise. It is also likely that after the rainy season the digester temperature rises which will also impact more gas production. The biogas gas production is presently $2.5 \mathrm{~m}^{3} /$ day.

\section{Temperature, $\mathrm{pH}$ and pressure dependence for biogas production}

The temperature of the material in the digester fluctuated between 28.7 and $32.6^{\circ} \mathrm{C}$ with an average of $30.3^{\circ} \mathrm{C}$, while pressure ranges from $5 \mathrm{kPa}-33 \mathrm{kPa}$ (Figure 5). The temperature is in line with the average temperature of the digesters

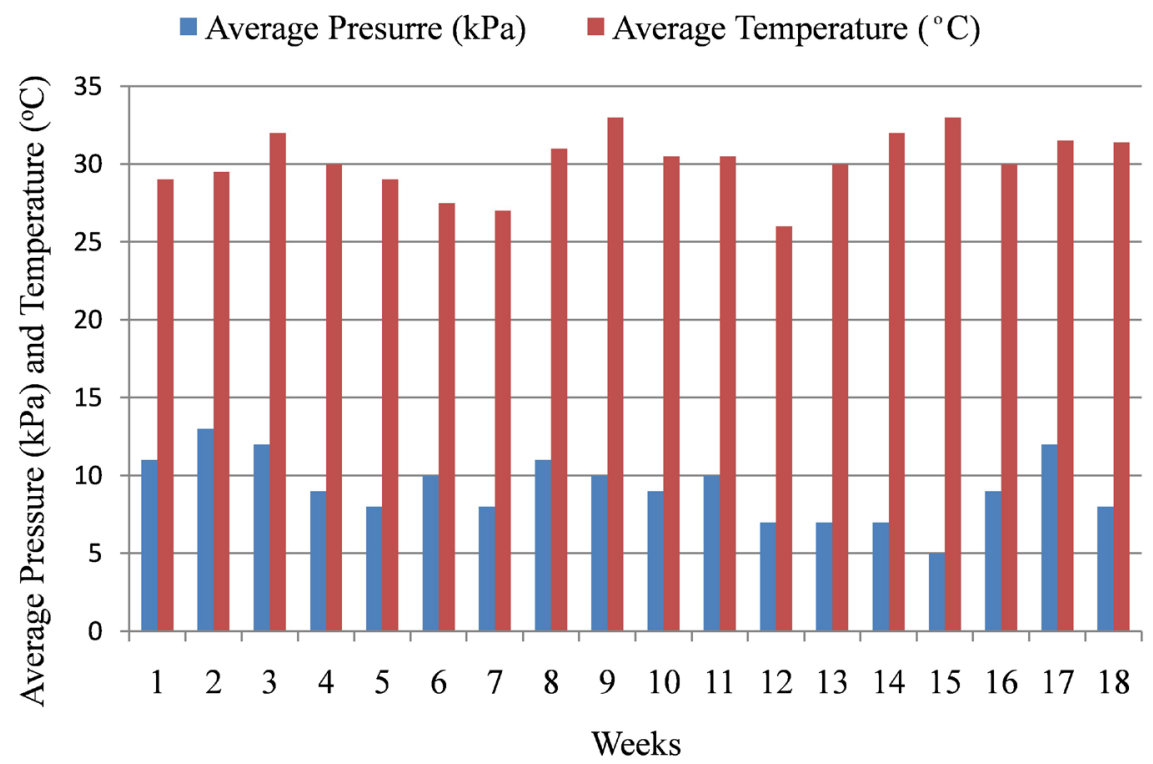

Figure 5. Variation of temperature and pressure in the digestion tank. 
rages between $26^{\circ} \mathrm{C}$ and $31^{\circ} \mathrm{C}$ [13]. This is relatively warm, and the fluctuations are minimal and they are good conditions for intensive anaerobic breakdown of organic matter by the bacteria. As the measurements took place in the cooler part of the year (April-August), during the warmer part of the year the temperatures will be even higher and so will be the gas production [14].

Enzymatic activity of the bacteria largely depends upon temperature, which is critical factor for methane production. The methanogens are inactive in extreme high and low temperatures. Once metabolism occurs exothermic reaction is helpful for the methane production. In case of mesophilic digestion, temperature range should be maintained between $30^{\circ} \mathrm{C}$ and $40^{\circ} \mathrm{C}$.

Satisfactory gas production takes place in the mesophilic range, the optimum temperature being $35^{\circ} \mathrm{C}$ [15]. Therefore, in cold climate the temperature of fermenting substances in the digester needs to be raised up to $35^{\circ} \mathrm{C}$. Gas production can be augmented significantly by increasing the temperature up to $55^{\circ} \mathrm{C}$ beyond which the production falls because of destruction of bacterial enzyme by elevated temperature. Thus, in case of thermophilic digestion, it should be between $45^{\circ} \mathrm{C}$ and $55^{\circ} \mathrm{C}$. On the other hand, when the ambient temperature goes down to $10^{\circ} \mathrm{C}$, gas production virtually stops. Gas production can be increased in the cold climate by means of proper insulation of digester [14]. Stafford [16], reported the effects of $\mathrm{pH}$ upon methane production from anaerobic digestion of dairy cattle manure maintained at $\mathrm{pH}$ levels of 5.0 to 7.6 and found that biogas and methane production was highest at $\mathrm{pH}$ of 7.0. The $\mathrm{pH}$ ranges from $6.3-8.0$ with the average of 6.9 (Figure 6).

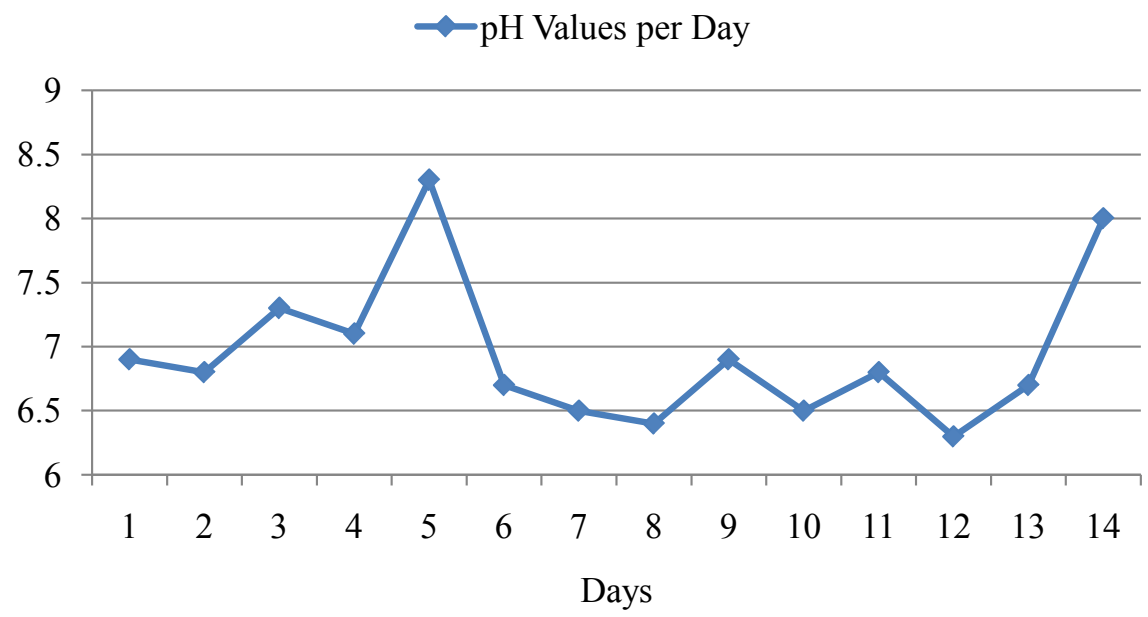

Figure 6. The $\mathrm{pH}$ values of mixture of substrates.

It should be noted that anaerobic degradation processes meet the requirement for both activities and cell growth of anaerobic microorganisms at $\mathrm{pH}$ of 5.5 - 8.5 [17]. The optimum $\mathrm{pH}$ values for the anaerobic digestion range between 6.4 7.2. The optimum $\mathrm{pH}$ for methanogens is 6.6 - 7.0 [18]. The growth rate of methanogenic bacteria is slower than the acidogenic bacteria. At lower $\mathrm{pH}$ values and higher feed rates the growth rate of acidogenic bacteria increases because 
acid formation during acidogenisis reduces the $\mathrm{pH}$ of the medium and inhibits the methanogenesis process [3].

\section{Hydraulic retention time}

The hydraulic retention time describes the retention time of water componentsnot the solids [19]. The total volume is the digester volume and the volume of the displacement tank, summing up to $38.5 \mathrm{~m}^{3}$. The solids will settle in the digester and remain there and turn to gas to a large extend. Adding up all the material entering, the daily feeding is $605 \mathrm{~kg}$ from which 505 liter are water and 105 are soft organic matter. With this feeding the digester will forever only discharge water with just traces of solids (less than $1 \%$ total solids). The hydraulic retention time is 38,500 liter divide by 605 liter/day $=63.6$ days Assuming I liter $=1$ $\mathrm{kg}$. The retention time for the solids is in principle 38,500 liter divide by 115 $\mathrm{kg} /$ day $=335$ days.

As the solids reduce to $5 \%$ the desludging period is mathematically 334 days $\times$ $0.05=6680$ days, which corresponds to 18.3 years. Considering that some dissolved particles are washed out with the water, the desludging interval is rather indefinite (meaning that desludging is never necessary), unless sand and stones are entering the system). Considering the high average temperature of $30^{\circ} \mathrm{C}$, the degradation will be fast and intense. Literature [20], indicated the warmer the digestion conditions the shorter the necessary retention time.

\section{Conclusion and Recommendations}

Healthcare waste treatment and its proper management are global issues with growing challenges especially in case of developing countries such as Tanzania. Biodigestion is a practical solution for disposing of pathological waste, with the added benefits of disposing of kitchen waste and generating biogas. Expert design is essential to fit into the often limited spaces in hospital campuses and ensure enough capacity to fully digest potentially infectious materials. More awareness with key stakeholders is needed on the value of the technology, to overcome prejudice against using biogas generated from placentas for cooking, to create ownership and transfer responsibility for sustainability. Subsidies are also needed to aid spread of the technology.

\section{Acknowledgements}

We wish to acknowledge Ministry of Health, Community Development, Gender, Elderly and Children (MoHCDGEC) who permitted researchers to construct the digester at Mwananyamala Regional Hospital premises and do the designed activity. Our heart appreciation goes to Mwananyamala Regional Hospital Officials and workers for their support, cooperation, help and hospitality during fieldwork.

\section{Conflicts of Interest}

The authors declare no conflicts of interest regarding the publication of this paper. 


\section{References}

[1] Gashaw, A. and Teshita, A. (2014) Co-Digestion of Ethiopian Food Waste with Cow Dung for Biogas Production. International Journal of Research, 1, 475-500.

[2] Kavitha, E.S. and Joseph, K. (2007) Biomethanation of Vegetable Wastes. Journal of the IPHE India, 3, 11-19.

[3] Imri, K. and Valeria, N. (2007) Experiments on the Maximum Biogas Production. 7 th International Multidisciplinary Conference, Baia Mare, Romania, 17-18 May 2007, 309-315.

[4] Pruess, A., Giroult, E. and Rushbrook, P. (1999) Safe Management of Wastes from Healthcare Activities. WHO, Geneva.

[5] Sridevi, P., Modi, M., Lakshmi, M. and Kesavarao, L. (2012) A Review on Integrated Solid Waste Management. Int. J. Eng. Sci. Adv. Technol, 2, 1491-1499.

[6] CMS (1996) Biogas Technology: A Training Manual for Extension, Support for Development of National Biogas Programme. Food and Agriculture Organization of the United Nations, FAO/TCP/Nep/4451-T.

[7] Biswas, A.K., Kumar, S., Babu, S.S., Bhattacharyya, J.K. and Chakrabarti, T. (2010) Studies on Environmental Quality in and Around Municipal Solid Waste Dumpsite. Resources, Conservation \& Recycling, 55, 129-134.

https://doi.org/10.1016/j.resconrec.2010.08.003

[8] Shen, Y., Linville, J.L., Urgun-Demirtas, M., Mintz, M.M. and Snyder, S.W. (2015) An Overview of Biogas Production and Utilization at Full-Scale Wastewater Treatment Plants (WWTPs) in the United States: Challenges and Opportunities towards Energy-Neutral WWTPs. Renewable \& Sustainable Energy Reviews, 50, 346-362. https://doi.org/10.1016/j.rser.2015.04.129

[9] Abdelgadir, A., Chen, X., Liu, J., Xie, X., Zhang, J., Zhang, K., Wang, H. and Liu, N. (2014) Characteristics, Process Parameters, and Inner Components of Anaerobic Bioreactors. BioMed Research International, 2014, Article ID: 841573. https://doi.org/10.1155/2014/841573

[10] Dhakal, N., Karki, A.B. and Nakarmi, M. (2015) Waste to Energy: Management of Biodegradable Healthcare Waste through Anaerobic Digestion. Nepal Journal of Science and Technology, 16, 41-48. https://doi.org/10.3126/njst.v16i1.14356

[11] Al Imam, O.I., Khan, M.Z.H., Sarkar, M.A.R. and Ali, S.M. (2013) Development of Biogas Processing from Cow Dung, Poultry Waste, and Water Hyacinth. International Journal of Natural and Applied Science, 2, 13-17.

[12] Lagrange, B. (1979) Biomethane, Principles Techniques Utilisations. EDISUD, Aix-en-Provence.

[13] Adekunle, A.S., Ibitoye, S.E., Omoniyi, P.O., Jilantikiri, L.J., Sam-Obu, C.V., Yahaya, T., Mohammad, B.G. and Olusegun, H.D. (2019) Production and Testing of Biogas Using Cow Dung, Jatropha and Iron Filins. Journal of Bioresources and Bioproducts, 4, 143-148.

[14] Pham, C.H., Vu, C.C., Sommer, S.G. and Bruun, S. (2014) Factors Affecting Process Temperature and Biogas Production in Small-Scale Rural Biogas Digesters in Winter in Northern Vietnam, Asian-Australas. Journal of Animal Science, 27, 1050-1056. https://doi.org/10.5713/ajas.2013.13534

[15] Karki, A. (1994) Biogas Installation with Elephant Dung at Machan Wildlife Resort, Chitwan, Nepal. Biogas Newsletter, No. 45.

[16] Stafford, M.G. (1982) The Effect of $\mathrm{pH}$ on Methane Production from Dairy Cattle Manure. Master's Thesis, University of Central Florida, Orlando. 
[17] Abbasi, T., Tauseef, S.M. and Abbasi, S.A. (2012) Biogas Energy. Springer, New York, 1-10. https://doi.org/10.1007/978-1-4614-1040-9_1

[18] Monnet, F. (2003) An Introduction to Anaerobic Digestion of Organic Wastes. Remade Scotland.

[19] Chandra, R., Takeuchi, H. and Hasegawa, T. (2012) Methane Production from Lignocellulosic Agricultural Crop Wastes: A Review in Context to Second Generation of Bio-Fuel Production. Renewable and Sustainable Energy Reviews, 16, 1462-1476. https://doi.org/10.1016/j.rser.2011.11.035

[20] Hilton, G.M., Houston, D.C. and Furness, R.W. (1998) Which Components of Diet Quality Affect Retention Time of Digesta in Seabirds? Functional Ecology, 12, 929-939. https://doi.org/10.1046/j.1365-2435.1998.00267.x 